\title{
環境負荷軽减のための研削スラッジリサイクル（機械 特性と研削スラッジ固形化処理条件の関係調査)
}

\author{
中村 莞爾* ·林 昭二*2 \\ Grinding Sludge Recycling to Reduce Environmental Load (Investigation of Relation between \\ Machine Characteristic and Grinding Sludge Briquetting Condition)
}

Kanji NAKAMURA and Shoji HAYASHI

Synopsis : Precision machinery parts maker uses many grinding machines, then by-produce a lot of grinding sludge. Most of which is dumped into landfills now as industrial waste. Recycling technology which enables environmental load reduction for ISO14001 and cost reduction at the same time was investigated. One of the key technologies to establish recycling system for grinding sludge is a development of practical briquetting machine which enables low-cost, energy save and compact. At first an AC servo motor drive briquetting machine was developed to analyze the best briquettig condition. Oil-based grinding sludge contains a lot of oil in the grinding swarf, so it is difficult to squeeze out because of its high viscosity. If pressing it with high pressure at the beginning of briqueting process, grinding sludge blows out. By using a test machine, the best briquetting condition was investigated for oil-based grinding sludge. Test results pointed out that the most important factor for briquetting is that the beginning of squeezing process needs to be controlled under low pressure with appropriate speed to avoid blow-out. Based on the test results, a low-cost practical briquetting machine was developed which could contribute to grinding sludge recycling for environmental load reduction.

Key words: recycle; grinding sludge; oil-based grinding sludge; briquette; briquetting machine; industrial waste.

\section{1. 緒言}

精密機械部品産業では多くの研削盤を使用しているため 多量の研削スラッジが発生し, その大部分が産業廃棄物 として埋め立て処理されているのが実情である。そこで ISO140012)の目的である環境負荷軽減とコストダウンが同 時に実現可能な研削スラッジリサイクル技術の開発に取り 組んできた。

その過程で研削スラッジのリサイクル推進に不可欠な廉 価版の研削スラッジ固形化処理機の開発を目的に, 油性研 削スラッジの固形化処理と機械制御との関係を調査した。 調査では試験用に開発した ACサーボモータで可変ピス卜 ンポンプを駆動する試験機を使用し，固形化处理条件と固 形化処理中の圧力変化 - 固形化処理後に排出されるブリ ケット比重との関係を調査することで最適な固形化処理条 件を明らかにした。その調査結果を基に油性研削スラッジ の固形化处理に必要な基本機能を備えた廉価版の研削ス ラッジ固形化処理機を開発したので，その開発経緯を報告 する。

\section{2. 試験方法}

\section{$2 \cdot 1$ 試験に使用した研削スラッジ固形化装置の仕様}

研削スラッジは綿状の細かい研削切粉に多量の研削液を 含んでいる。そして研削液が油性の場合は油の高い粘性が 障害となって綿状の研削切粉から搾り出し難く, 固形化処 理が難しくなることが判っている。油性研削スラッジの場 合加圧初期段階から無理に大きな力を加えて固形化处理し ようとすると，加圧開始直後に研削切粉と研削液がへドロ 状に混合して噴き出し，固形化処理ができなくなる3》。そ のため研削スラッジの固形化処理は単純に力を加えて押し 固めるのではなく，固形化処理のプロセスを下記の $2 工$ 程 に分けて考えて前半は多量に含まれる研削液を圧搾する脱 液工程, 後半は脱液後の研削切粉を押し固める固形化工程 とし，それぞれの工程に合わせて最適な制御が可能な機械 とした。

・脱 液 工 程：多量に含まれる研削液を圧搾するため低圧 で加圧前進する

- 固形化工程: 研削液圧控後の研削切粉を押し固めるため 高圧で加圧前進する

今回試験用に開発した研削スラッジ固形化处理機は油圧源

平成 18 年 8 月 22 日受付 平成 18 年 10 月 19 日受理 (Received on Aug. 22, 2006; Accepted on Oct. 19, 2006)

* 名古屋工業大学工業研究科物質工業専攻人-学院生 (Graduate Student of Materials Engineering, Nagoya Institute of Technology, Gokiso-cho Showa-ku Nagoya 430-0919)

*2 名古屋工業大学大学院ながれ領域 (Graduate Student of Materials Engineering, Nagare College, Nagoya Institute of Technology) 
にFig. 1に示すような ACサーボモータで可変ピストンポ ンプを駆動し，圧力センサーと回転センサーを使用してポ ンプの吐出流量と吐出圧力を制御する方式を採用した。な お油圧ポンプの特性は下記の2段階切り替えで, ACサー ボモータの回転数を制御して流量を変えることで加圧シリ ンダの速度を制御する。

・低圧（ポンプ吐出压力 $3.9 \mathrm{MPa} \cdots \phi 70 \mathrm{~mm}$ ブリケット面 圧換算 $50 \mathrm{MPa}) \cdot$ 大流量 $(70 \mathrm{cc} / \mathrm{rev})$

-高压（ポンプ吐出压力 $27.5 \mathrm{MPa} \cdots \phi 70 \mathrm{~mm}$ ブリケット面 圧換算 $350 \mathrm{MPa}) \cdot$ 小流量 $(10 \mathrm{cc} / \mathrm{rev})$

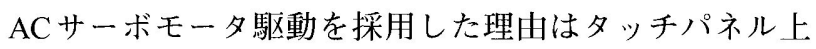
で固形化処理条件を簡単に変更できるため多種多様な試験 が効率良くでき，しかも省エネを実現できるためである。

固形化処理を行う加圧部の構造はFig. 2に示すような円 筒状の金型に研削スラッジを投入し, 金型と加圧ロッドの 機械的な隙間から研削液を排出しながら最終的に研削切粉 を押し固める方式である。加圧工程は下記の項目 1) 7)を 入力して加圧条件を設定し，Fig. 3に示すように加压ロッ ドを制御する。

1) 高速前進速度 $(\mathrm{mm} / \mathrm{s})$ : 最後退位置から高速前進位置ま での前進速度

2) 高速前進位置 $(\mathrm{mm})$ : 最後退位置から高速前進速度で

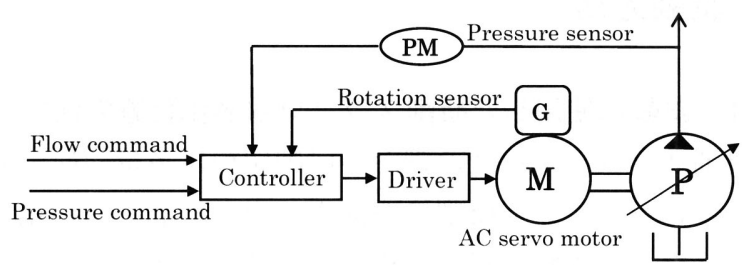

Fig. 1. Hydraulic pump control system.

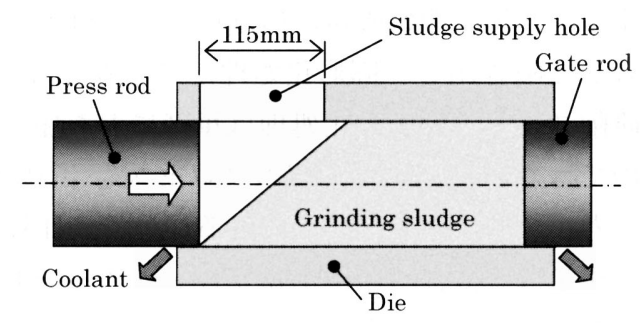

Fig. 2. Press mechanism for grinding sludge.

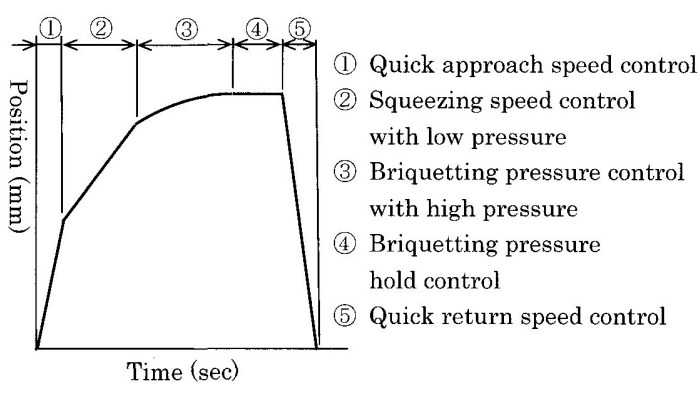

Fig. 3. Press rod control.
前進する距離

3) 脱液圧力 $(\mathrm{MPa})$ ：脱液を完了する圧力（ $\phi 70 \mathrm{~mm}$ ブリ ケット面圧換算)

4) 脱液前進速度 $(\mathrm{mm} / \mathrm{s})$ : 脱液圧力到達まで指令速度

5) 固形化圧力 $(\mathrm{MPa})$ : 固形化処理 $の$ 最終到達压力 ( $\phi 70 \mathrm{~mm}$ ブリケット面圧換算)

6) 加圧保持時間 (s)：固形化圧力到達後に固形化圧力を保 持する時間

7) 高速後退速度 $(\mathrm{mm} / \mathrm{s})$ ：加圧保持完了後に最後退位置に 戻る後退速度

実際に油性研削スラッジを正常に固形化処理した時の圧力 変化の実例をFig. 4 に示す。

\section{$2 \cdot 2$ 試験に使用した研削スラッジ}

研削スラッジは油性研削液の研削ラインで発生した研削 切粉を加圧式べルトフィルタで滤過したものを使用した。 研削スラッジの詳細は下記のとおりである。

・被削材：焼入れ後のSUJ2 (HRC60)

- 研削液の動粘性： $23.8 \mathrm{cSt}\left(20^{\circ} \mathrm{C}\right)$

·含油率 : 約 $50 \mathrm{wt} \%$

\section{$2 \cdot 3$ 金型と最大面圧}

金型内径 $\phi 70 \mathrm{~mm}$ でブリケットに加わる最大面圧は $350 \mathrm{MPa}$ (加圧シリンダ最大推力 $137 \mathrm{t}$ ）。

\section{4 圧力変化調査}

固形化処理中の加圧シリンダ内に発生する背圧変化を検 出して記録した。

\section{$2 \cdot 5$ ブリケット特性調査}

ブリケットの外徍 $(\mathrm{mm})$, 幅 $(\mathrm{mm})$, 重さ $(\mathrm{g})$ を測定して比 重を算出した。

\section{$2 \cdot 6$ 試験時の気温}

試験は夏季に気温 $25 \sim 30^{\circ} \mathrm{C}$ で実施した。ただし冬季の 噴き出し対策効果の確認試験のみ気温 $3^{\circ} \mathrm{C}$ で実施した。

\section{3. 試験結果}

\section{$3 \cdot 1$ 油性研削スラッジ固形化処理の最適な加圧条件調查} 試験は機械を半日程度稼動させ熱的に安定した状態で実 施した。その結果は下記のとおりである。

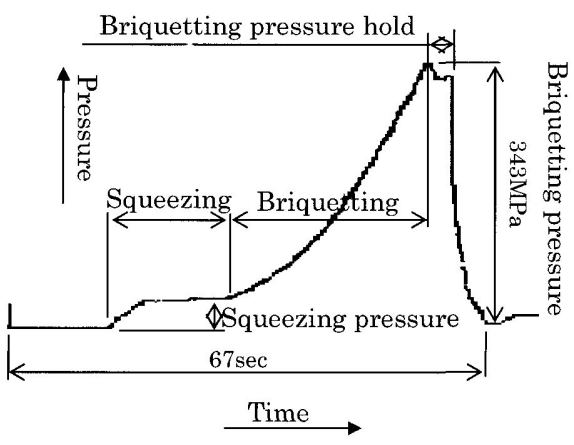

Fig. 4. Pressure curve of press cylinder. 


\section{$3 \cdot 1 \cdot 1$ 高速前進速度の最適設定値調查}

高速前進速度を $25,30,40 \mathrm{~mm} / \mathrm{s}$ に設定した時の圧力変 化を Fig. 5 に示す。な扎高速前進位置は研削スラッジ投入 口を塞ぐ位置である $115 \mathrm{~mm}$ とした。高速前進速度 30 ， $40 \mathrm{~mm} / \mathrm{s}$ の矩印で示す部分で発生している压力低下は脱液 前進速度に切り替わる時点で金型内の内圧が急激に上昇し て研削スラッジの一部がへドロ状となって噴き出したこと を意味し正常ではないことから，小さな圧力低下に留まっ ている $30 \mathrm{~mm} / \mathrm{s}$ が高速前進速度の上限と考えられる。この 試験結果より高速前進速度は $30 \mathrm{~mm} / \mathrm{s}$ とした。

\section{$3 \cdot 1 \cdot 2$ 脱液圧力の最適設定值調査}

脱液圧力を $19.6 \mathrm{MPa} ， 29.4 \mathrm{MPa} ， 49.0 \mathrm{MPa}$ に設定した時 の圧力変化を Fig. 6 に示す。この試験結果より脱液圧力を $49.0 \mathrm{MPa}$ に設定した場合は脱液压力に到達するまでに時間 が脚かり，サイクルタイムが非常に長くなることが判った。 なお脱液圧力 $19.6 \mathrm{MPa}$ で脱液工程から固形化工程に切り換 え後, 高圧で急激に加圧しても噴き出しを示す压力低下は 発生していないことから, 高い含油率の研削スラッジは脱 液開始時点で噴き出しを発生させなければ，それ以降は急 激な加圧をしても噴き出しは発生しないと考えられる。こ の結果より高い脱液圧力まで低圧で無理なく脱液でき，し
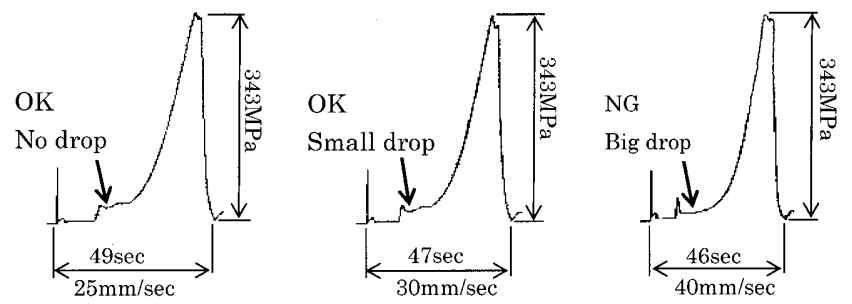

Fig. 5. Pressure curve at different quick approach speed.
かもサイクルタイムに影響の出ない $29.4 \mathrm{MPa}$ が最適な設定 值と考えられるため脱液压力は $29.4 \mathrm{MPa}$ とした。

\section{$3 \cdot 1 \cdot 3$ 脱液前進速度の最適設定值調查}

高速前進速度 $30 \mathrm{~mm} / \mathrm{s}$, 脱液圧力 $29.4 \mathrm{MPa}$ として脱液前 進速度を $1.35 \mathrm{~mm} / \mathrm{s}, 2.7 \mathrm{~mm} / \mathrm{s}, 3.5 \mathrm{~mm} / \mathrm{s}, \quad 5.0 \mathrm{~mm} / \mathrm{s}$ に設定 してサイクルタイムを測定した結果を下記に示す。

$1.35 \mathrm{~mm} / \mathrm{s}: 120 \mathrm{~s}, \quad 2.7 \mathrm{~mm} / \mathrm{s}: 49 \mathrm{~s}, \quad 3.5 \mathrm{~mm} / \mathrm{s}: 49 \mathrm{~s}$,

$5.0 \mathrm{~mm} / \mathrm{s}: 49 \mathrm{~s}$

この試験結果より脱液前進速度を $2.7 \mathrm{~mm} / \mathrm{s}$ 以上にしてもサ イクルタイムは変わらないことが判った。この原因として は油性研削液の場合粘性が高く排出し難いため, 脱液前進 速度が $2.7 \mathrm{~mm} / \mathrm{s}$ 以上では研削液の排出より加圧ロッドの前 進の方が上回り脱液圧力 $29.4 \mathrm{MPa}$ に到達する時間が同じに なるためと考えられる。この試験結果より脱液速度は $2.7 \mathrm{~mm} / \mathrm{s}$ とした。

\section{$3 \cdot 2$ ブリケット特性の短時間連続調查結果}

最適な加圧条件を設定後，機械稼働開始後のブリケット を連続106個採取して厚さと重さの変化を測定して比重を 算出した結果を Fig. 7 に示す。この試験結果より機械稼動 開始直後の 10 個程度は比重が小さいことが判る。ブリ ケットを観察した結果, 固形化が不十分で軟らかく十分脱 液されていないことが確認された。

\section{(加圧条件)}

高速前進速度 : $30 \mathrm{~mm} / \mathrm{s}$, 脱液前進速度 : $2.7 \mathrm{~mm} / \mathrm{s}$, 脱 液圧力： $29.4 \mathrm{MPa}$, 固形化圧力 : $343 \mathrm{MPa}$

\section{$3 \cdot 3$ ブリケット特性の長時間連続調査結果}

7 時間連続稼働時の 1 時間毎のブリケット厚さと重さを 測定して比重を算出した結果を Fig. 8に示す。なおデータ は1時間毎に採取した 5 個の平均值を示している。この試
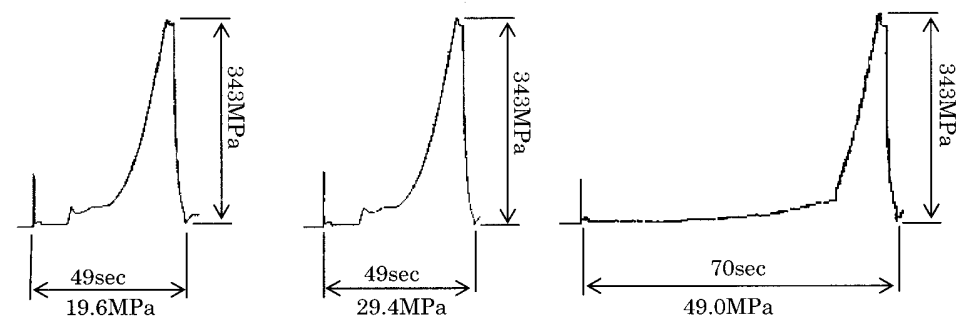

Fig. 6. Pressure curve at different squeezing pressure.

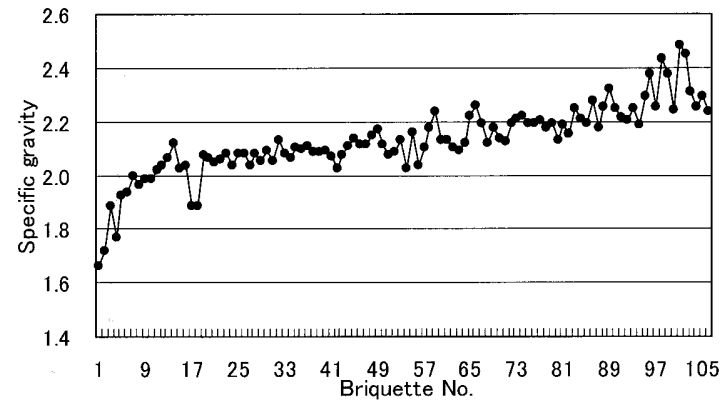

Fig. 7. Specific gravity trend from machine start (every briquette).

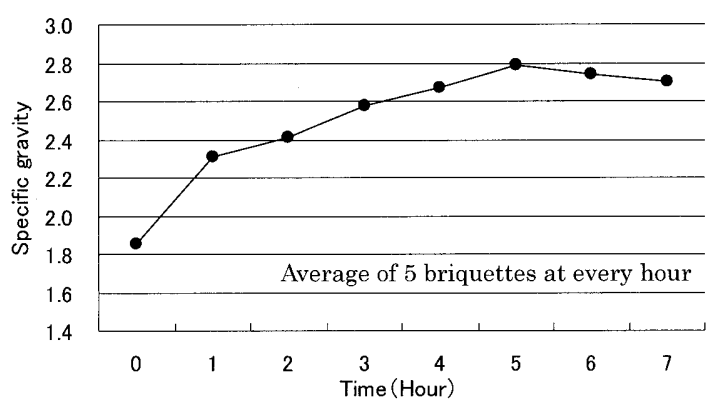

Fig. 8. Specific gravity trend from machine start ( $1 \mathrm{~h}$ interval). 


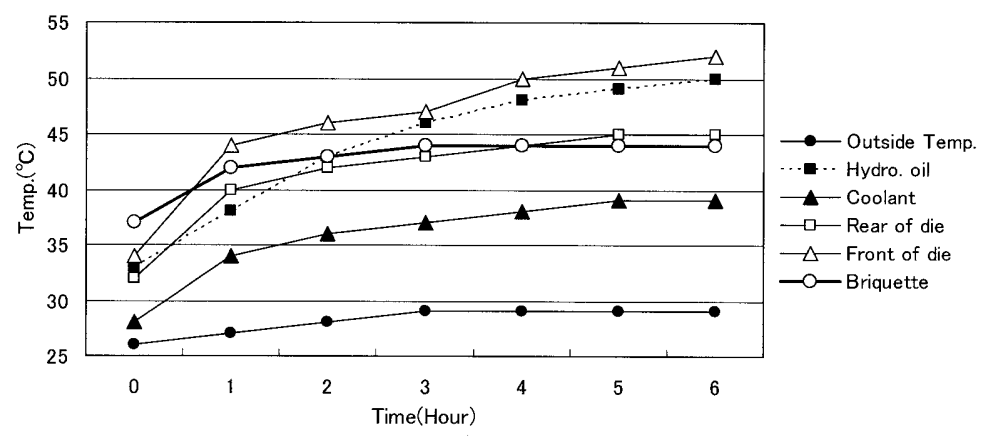

Fig. 9. Temperature characteristic of briquetting machine.

験結果より固形化処理は機械起動後 4 時間程度して安定す ることが判る。なお加圧条件は $3 \cdot 2$ と同じである。

\section{4 研削液回収率と処理能力}

油性研削スラッジを固液分離・固形化処理した場合，コ ストダウンメリットとして高価な油性研削液の回収が重要 である。そこで7時間連続稼動時に回収した研削液とブリ ケット測定結果より, 研削液回収率と研削スラッジ固形化 处理機の処理能力を推定すると下記のようになる。

(1)研削液回収率

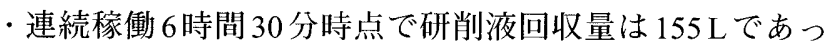
たことから，時間当りの研削液回収量は $155 \div 6.5=$ $23.8 \mathrm{~L} / \mathrm{h}$ である。

·7 時間連続稼動時のブリケット平均重量は $381 \mathrm{~g} て ゙$ 平均 サイクルタイムは $50 \mathrm{~s}$ であったことから，時間当りのブ リケット重量は $381 \times 3600 \div 50 \div 1000=27.4 \mathrm{~kg}$ である。

・時間当りの研削液回収量の重量は $23.8 \times 0.9=21.4 \mathrm{~kg}$ (0.9：研削液の比重) であることから，回収された研削 液の研削スラッジに対する重量比率は $21.4 \div(21.4+$ $27.4) \times 100=44 \mathrm{wt} \%$ となる。

以上より含油率 $50 \mathrm{wt} \%$ の研削スラッジから固形化処理に よって回収された研削液の回収比率は $44 \div 50 \times 100=88 \%$ となり高い回収率が得られることが確認された。

(2)研削スラッジ固形化处理機の時間当たりの处理能力はブ リケット重量と回収研削液重量より $27.4+21.4=48.8 \mathrm{~kg} / \mathrm{h}$ である。

\section{5 連続稼働による温度変化調査結果}

油性研削スラッジの固形化処理は油性研削液の粘性と大 きく関係していることから連続稼動時の機械・研削液・ブ リケットの温度変化を測定した結果を Fig. 9に示す。測定 結果は稼動開始直後 1 時間の温度上昇は大きいが，その後 は緩やかになり4時間程度で熱的に安定することを示して おり，ブリケット特性の長時間連続調査結果の比重が 4 時 間程度で安定することを裏付けるものである。

\section{6 機械起動直後の噴き出し調査と対策}

$3 \cdot 6 \cdot 1$ 夏季の起動直後の噴き出し現象と対策の検討

夏季（気温： $25^{\circ} \mathrm{C}$ ）の起動時にブリケット 1 個目の研削 スラッジの噴き出し状況を調查した。その結果 Fig.10に示

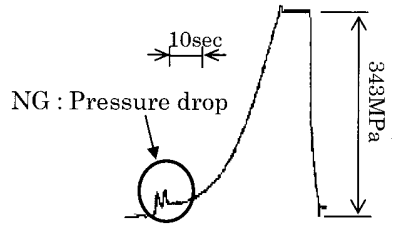

Fig. 10. Pressure curve for the first briquette at summer $\left(25^{\circ} \mathrm{C}\right)$.

Table 1. Test results for blow-out with quick approach position and speed.

\begin{tabular}{|c|c|c|c|c|}
\hline $\begin{array}{c}\text { Test } \\
\text { No. }\end{array}$ & $\begin{array}{c}\text { Quick approach } \\
\text { position }\end{array}$ & $\begin{array}{c}\text { Quick approach } \\
\text { speed }\end{array}$ & C.T. & $\begin{array}{c}\text { Test results } \\
\text { at machine start }\end{array}$ \\
\hline 1 & $115 \mathrm{~mm}$ & $30 \mathrm{~mm} / \mathrm{sec}$ & $55 \mathrm{sec}$ & Blow out sometimes \\
\hline 2 & $80 \mathrm{~mm}$ & $\prime \prime$ & $\prime \prime$ & $"$ \\
\hline 3 & $115 \mathrm{~mm}$ & $20 \mathrm{~mm} / \mathrm{sec}$ & $61 \mathrm{sec}$ & No blow out \\
\hline 4 & $\prime \prime$ & $15 \mathrm{~mm} / \mathrm{sec}$ & $74 \mathrm{sec}$ & $"$ \\
\hline
\end{tabular}

C.T:Cycle Time

すように脱液開始直後に2回の圧力低下が発生し, 軽度の 噴き出しが観察された。このことから冬季には研削油の粘 性が高くなり噴き出しが無視できなくなることが予想され るので対策が必要と推定される。冬季に扔ける起動直後の 噴き出し防止をするため，高速前進位置と高速前進速度に 着目して試験を実施した。その結果を Table 1に示す。

試駼結果から噴き出し防止は高速前進位置を小さくして も効果がなく, 高速前進速度の最適設定值調查のテスト結 果で示した時と同様に高速前進速度との関係で決まってい ることから，高速前進速度を落とすことが有効と考えられ る。そこで冬季起動時の噴き出し対策として最初の 10 個 の前進速度（高速前進速度と脱液前進速度）の設定值を $50 \%$ に落とす制御を追加することにした。

$3 \cdot 6 \cdot 2$ 冬期の起動直後の噴き出し調查

研削油の粘性が最も高くなる冬季 (気温： $3^{\circ} \mathrm{C}$ ) の状況 を調查した。な抢研削油の動粘性は $0^{\circ} \mathrm{C} て ゙$ 約 $40 \mathrm{cSt}$ である。 起動直後 1 個目のブリケットの圧力変化を Fig.11に示す。 この試験結果から高速前進速度と脱液前進速度を $50 \%$ に して加圧することで噴き出しを発生させずに正常に固形化 できることが確認された。 


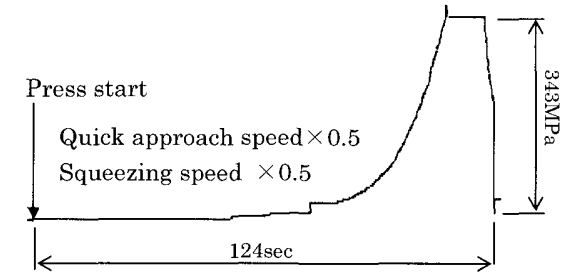

Fig. 11. Pressure curve for the first briquette at winter $\left(3^{\circ} \mathrm{C}\right)$.

\section{4. 考察}

今回の試験結果より，安定した固形化処理を実施するた めには噴き出しを避けることが重要で，噴き出しに関して 下記の事実を確認した。

・高速前進速度を速く設定すると噴き出しが発生する。

・低い脱液圧力でも，ある程度脱液が進行しているため固 形化工程で急激な加圧をしても噴き出しは発生しない。

・機械起動直後は噴き出しが発生しやすいが, 粘性の高い 冬季でも起動直後のみ前進速度を遅くすることで噴き出 しの対策ができた。

上記の結果より安定した固形化処理をするためには加圧 初期段階で金型内の含油率の高い油性研削スラッジに無理 な力を加えて内圧を急激に上昇させないことが重要である と考えられる。特に機械起動直後は研削油の粘性が高いた め, その現象が顕著に現れるので注意が必要である。以上 のことから噴き出しの原因は研削スラッジが含油率の高い 状態で急激な加圧を受けると本来糸屑状で絡み合っている 研削切粉が，その状態が保持できなくなり油性研削液と均 等に混合して機械的な隙間から流出するためと考えられ る。

\section{5. 廉価版研削スラッジ固形化処理機の開発}

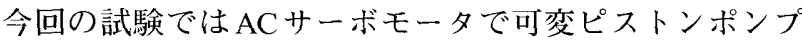
を駆動して圧力と速度が制御可能な高価な試験機を使用し
たが，試験の結果噴き出しが発生しないようにするために は加圧初期段階で金型内の内圧が急激に上がらない加圧速 度を設定すれば良いことが判った。そこで油圧駆動源を ACサーボモータでピストンポンプを駆動する方式から IPMモータ4)をインバータで回転制御してギアポンプの吐 出流量を制御する簡単な速度制御方式に変更し，今回の試 験結果に基づいて噴き出しの発生しない加圧速度を設定す ることでコストダウンと省エネを同時に実現した廉価版の 研削スラッジ固形化処理機を開発した。なお試験機で多量 の研削スラッジを処理した結果，研削スラッジが污泥物質 であることから下記の項目も研削スラッジ固形化処理機を 普及させるためには非常に重要であることが判ったので， 開発機は十分配慮した構造とした。

・メンテナンス容易な機械（機内清掃，金型交換等）

・機械スライド・油圧機器への研削スラッジの侵入防止

\section{6. 結言}

企業が循環型社会 ${ }^{5)}$ に適応して今後も生産活動を継続す るためには研削スラッジのリサイクルは避けて通れない課 題である。しかし研削スラッジのリサイクルを推進するた めには今回開発した廉価版の研削スラッジ固形化処理機を 提供するだけでは不十分で，固形化処理後のブリケットを 資源として再利用するリサイクルルートの構築が不可欠で ある。今後は鉄鋼業界の理解と協力が得られるよう働きか けて研削スラッジのリサイクルを推進する。

\section{文献}

1) 中山哲夫：廃棄物処理・再資源化技術ハンドブック，(1993) 5 .

2) 吉澤 正：ISO14001 環境マネジメント便覧, (1999), 60

3 ) K.Nakamura and S.Hayashi: Tetsu-to-Hagané, 92 (2006), No. 5, 56.

4 ）モータ技術実用ハンドブック編集委員会：モ一タ技術実用八 ンドブック，(2001), 771.

5 ) 廃棄物・リサイクル法研究会監修：廃棄物・リサイクル六法, (2004), 3 . 